\title{
Activity Card Sort
}

National Cancer Institute

\section{Source}

National Cancer Institute. Activity Card Sort. NCI Thesaurus. Code C129985.

An assessment tool developed to measure levels of activity eng agement in older adults.

Participants sort cards depicting people eng aged in various activities into categories

representing whether the activity is part of the individual's routine. 